\title{
Multimodality imaging aided diagnosis of early zonular dehiscence following laser peripheral iridotomy
}

\author{
Jyoti Shakrawal, Tanuj Dada, Karthikeyan Mahalingam
}

Glaucoma Services, Dr Rajendra Prasad Centre for Ophthalmic Sciences, All India Institute of Medical Sciences, New Delhi, India

Correspondence to Dr Karthikeyan Mahalingam; kalingachit@gmail.com

Accepted 23 July 2020
Check for updates

(c) BMJ Publishing Group Limited 2020. No commercial re-use. See rights and permissions. Published by BMJ.

To cite: Shakrawal J, Dada T, Mahalingam K. BMJ Case Rep 2020;13:e236689. doi:10.1136/bcr-2020 236689

\section{DESCRIPTION}

A 57-year-old man presented with diminution of vision in left eye (LE) for 2 days. He underwent both eyes laser peripheral iridotomy (LPI) once prior to his symptoms. On examination, he had right eye (RE) vision of 6/9, LE of 1/60 and intraocular pressure (IOP) of $14 \mathrm{~mm} \mathrm{Hg}$ in RE and $44 \mathrm{~mm} \mathrm{Hg}$ in LE on topical timolol $(0.5 \%)$ and brimonidine $(0.2 \%)$. On slit-lamp examination, LE had diffuse corneal oedema, shallow anterior chamber (AC) with dispersed blood, fixed mid dilated pupil with two superior large iridotomies with surrounding iris chafing and a cataractous lens (figure 1A). RE had a shallow AC with patent iridotomy. Fundus examination showed a cup-disc ratio of $0.6: 1 \mathrm{in} R E$ and 0.7:1 in LE. He was started on oral acetazolamide and glycerol along with maximum topical glaucoma medications. We suspected LE lens subluxation, which was confirmed by ultrasound biomicroscopy which revealed zonular dehiscence with dispersed lens matter superiorly (corresponding to LPI site) with inferior lens tilt (figure 1B). Anterior segment Optical Coherence Tomography (ASOCT) also showed narrow angles with scattered blood in $\mathrm{AC}$ and membranes over iris (figure 1C). After giving intravenous mannitol $(1 \mathrm{~g} / \mathrm{kg}) 15$ min prior, LE phacoemulsification was attempted with taking all precautions for subluxated lens. Intraoperatively
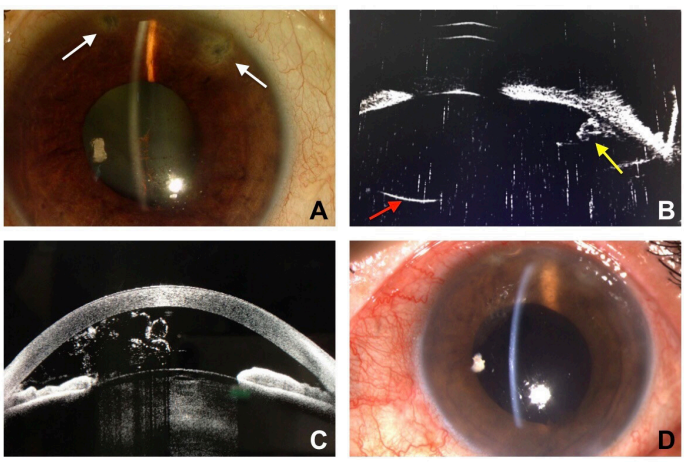

Figure 1 (A) Slit-lamp image of left eye showing shallow anterior chamber with two large superior peripheral iridotomies with iris chafing (white arrows). (B) Ultrasound biomicroscopy of left eye showing superior zonular dehiscence with dispersed lens matter (yellow arrow) and inferior lens tilt (red arrow). (C) Anterior segment OCT picture of left eye showing showed narrow angles, scattered blood in anterior chamber and superior membranes over iris superiorly. (D) Postoperative day 2 clinical image showing a deep anterior chamber.

\section{Learning points}

- During laser peripheral iridotomy (LPI), if a patent iridotomy is not achieved after one or two laser shorts, chipping of the remaining lamellar area should be done with low energy and multiple attempts using higher energy in LPI should be avoided in a single sitting.

- Dilated examination of lens on follow-up must be encouraged after LPI.

- Surgeon must be cautious to look for occult lens subluxation or zonular dehiscence during cataract surgery and prepare with iris hooks or three-piece intraocular lens in patients with such suspicion.

capsular tension ring placement was attempted after emulsifying the nucleus to stabilise the bag, but was unsuccessful and surgery was converted to lensectomy due to highly unstable bag with $>200^{\circ}$ subluxation and patient was left aphakic. Postoperatively day 2 , vision was $6 / 18$ with $+10 \mathrm{D}$ lens and IOP was $12 \mathrm{~mm} \mathrm{Hg}$ with a stable AC (figure 1D).

Complications of LPI include transient blurring of vision, transient raised IOP, diplopia, corneal damage, minor iris bleed, uveitis, localised lens or zonular damage/subluxation, closure of iridotomies, retinal burns and detachment. ${ }^{1}$ Zonular dehiscence following LPI is rare and has been reported in few cases. ${ }^{2-4}$ Shockwaves from LPI could have damaged the already predisposed or weak zonules causing lens subluxation or dislocation. Athanasiadis et al reported LPI as a possible cause for the zonular dehiscence which occurred during the phacoemulsification. ${ }^{5}$ In most of these cases, lens subluxation or dislocation occurred after months to years after LPI and evidence of causality between them was inadequate. ${ }^{6} \mathrm{Hu}$ et al also reported an occult lens subluxation related to LPI after 5 days of treatment. ${ }^{4}$ We report a rare case of early zonular dehiscence only after 2 days of LPI with the possibility of multiple attempts of peripheral iridotomy of high energy (evident by two visible large peripheral iridotomy with surrounding iris chafing) in a single sitting leading to zonular dehiscence.

Contributors JS, TD and KM involved in planning, conducting, reporting, conception and design, acquisition of data or analysis and interpretation of data.

Funding The authors have not declared a specific grant for this research from any funding agency in the public, commercial or not-for-profit sectors. 
Competing interests None declared.

Patient consent for publication Obtained.

Provenance and peer review Not commissioned; externally peer reviewed.

\section{REFERENCES}

1 Murphy PH, Trope GE. Monocular blurring. A complication of YAG laser iridotomy. Ophthalmology 1991;98:1539-42.

2 Mutoh T, Barrette KF, Matsumoto Y, et al. Lens dislocation has a possible relationship with laser iridotomy. Clin Ophthalmol 2012;6:2019-22.
3 Seong M, Kim MJ, Tchah H. Argon laser iridotomy as a possible cause of anterior dislocation of a crystalline lens. J Cataract Refract Surg 2009;35:190-2.

4 Hu R, Wang $X$, Wang $Y$, et al. Occult lens subluxation related to laser peripheral iridotomy. Medicine 2017:96:e6255.

5 Athanasiadis Y, de Wit DW, Nithyanandrajah GA, et al. Neodymium:YAG laser peripheral iridotomy as a possible cause of zonular dehiscence during phacoemulsification cataract surgery. Eye 2010;24:1424-5.

6 Kumar H, Mansoori T, Warjir GB, et al. Lasers in glaucoma. Indian J Ophthalmol 2018:66:1539-53.

Copyright 2020 BMJ Publishing Group. All rights reserved. For permission to reuse any of this content visit

https://www.bmj.com/company/products-services/rights-and-licensing/permissions/

BMJ Case Report Fellows may re-use this article for personal use and teaching without any further permission.

Become a Fellow of BMJ Case Reports today and you can:

- Submit as many cases as you like

Enjoy fast sympathetic peer review and rapid publication of accepted articles

- Access all the published articles

Re-use any of the published material for personal use and teaching without further permission

Customer Service

If you have any further queries about your subscription, please contact our customer services team on +44 (0) 2071111105 or via email at support@bmj.com.

Visit casereports.bmj.com for more articles like this and to become a Fellow 